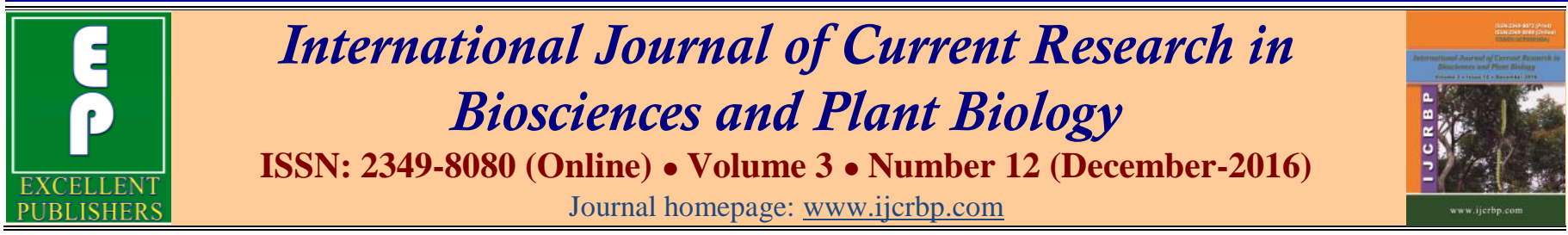

Original Research Article

doi: http://dx.doi.org/10.20546/ijcrbp.2016.312.010

\title{
Assessment of Bioavailability of Chromium (Cr), Vanadium (V) and Uranium (U) in Wild Plants in Siwaqa Area, Central Jordan
}

\author{
Asma F. Bzour ${ }^{*}$, Hani N. Khoury¹ and Sawsan A. Oran² \\ ${ }^{1}$ Department of Geology, University of Jordan, P. O Box 11942, Jordan \\ ${ }^{2}$ Department of Biological Sciences, University of Jordan, Jordan \\ *Corresponding author.
}

\begin{abstract}
A b s t r act
Surficial soil enriched with U-rich encrustations and green Cr-rich smectite covers large areas of Siwaqa, Central Jordan. The wide distribution of redox-sensitive elements (RSE) as chromium $(\mathrm{Cr})$, vanadium $(\mathrm{V})$ and uranium $(\mathrm{U})$ in the top soil are related to the weathering action of alkaline surface and groundwater on the parent rocks. The bioavailability, distribution, sorption, and ecotoxicity of $\mathrm{Cr}, \mathrm{V}$, and $\mathrm{U}$ of the wild plants and top soils in the study area were investigated. A total number of 23 surface soil samples and 23 plant samples were collected and analyzed for the most toxic elements ( $\mathrm{Cr}, \mathrm{V}$ and $\mathrm{U}$ ) by using Induced Coupled Plasma-Mass Spectrometry (ICP- MS). The average $\mathrm{Cr}, \mathrm{V}$ and $\mathrm{U}$ values in the soil was $59,6.6$ and $67 \mathrm{mg} / \mathrm{kg}$ respectively. The transfer factors (TFs) of these elements have indicated that the highest $\mathrm{Cr}$ and $\mathrm{V}$ values ( 0.6 and 0.26 respectively) were in the wild plants and particularly in Bellevalia sp. The highest TF for U (0.25) was recorded in Onopordum transjordanicum. The uptake of elements by plants was dependent on the plant species and the concentration of elements in the soil. Differences between TFs values of these elements in the various plant species are related to the different characteristics of the plants. The comparative uptake of the studied RSE was affected by the numerous physical, chemical and biological conditions of the soil. The results of this work provide a valuable knowledge for understanding the bioavailability of some toxic elements in the soil and plants of Central Jordan. The results are expected to be of great help for the Jordanian Uranium Mining Company during their environmental risk assessments.
\end{abstract}

\section{Introduction}

Chromium (Cr), Uranium (U) and Vanadium (V) are naturally occurring trace elements in rocks and soil environment resulted from pedogenetic processes of weathering (Pierzynsiki et al., 2000). These elements are important in contaminating surface and ground waters and decreasing crop production as a result of

\section{Article Info}

Accepted: 27 November 2016 Available Online: 06 December 2016

\section{Ke yword s}

Bioavailability Ecotoxicity

Environmental impact assessment

Trace elements

Transfer factor 
bioavailability, mobility, and toxicity (Shiowatana et al., 2001). Heavy metals distribution in soils takes place as a result of mineral precipitation and dissolution, ion exchange, adsorption, aqueous complexation, biological immobilization and mobilization, and plant uptake (Levy et al., 1992). Potentially toxic elements in soils and plants may come from the bedrock itself and anthropogenic sources like solid or liquid waste deposits (Wilson and Pyatt, 2007).

Plants are important components of ecosystems as they transfer elements from abiotic into biotic environments. Water, air and soils are the primary sources of elements from the environment to plants (Hamilton, 1995). All plants have the ability to accumulate essential elements from the soil and need different concentrations from these elements for growth and development. This ability also allows plants to accumulate other non-essential elements which have not known biological function (Djingova and Kuleff, 2000). Several studies have been carried out to evaluate and describe the accumulation of toxic trace elements and its impacts on the plant diversity were investigated by many authors and in different regions (Tomé et al., 2002; Chen et al., 2005).

The soils and plants contain all naturally occurring radioactive elements with half-lives comparable to the age of the earth, although their concentrations in plants may be rather low (Buck et al., 1996). The phytochemistry of honey samples and plant species were studied and the trace elements of $\mathrm{Cu}, \mathrm{Zn}, \mathrm{Ni}, \mathrm{Cr}$ and $\mathrm{Mn}$ were investigated. The results have indicated that the differences in the values of trace elements were controlled by pollens where the honeybees fed (Atrouz et al., 2004). The uptake of heavy metals by plant parts is real and not due to contamination by aerosols and was best illustrated by highest Ni uptake index in Atriplex leuceclada (Abed and Al-Eisawi, 1994).

Top soils of Central Jordan are enriched in redox sensitive trace elements such as $\mathrm{U}, \mathrm{Cr}, \mathrm{Zn}, \mathrm{Cr}, \mathrm{Ni}, \mathrm{Cu}$, $\mathrm{Co}$, As and $\mathrm{Cd}$ in the form of sulphides and selenides (Nassir and Khoury, 1982; Khoury and Nassir, 1982; Khoury, 2012; Fourcade et al., 2007; Techer et al., 2006; Khoury et al., 2014 and 2015). The highest concentrations of trace elements from Central Jordan are present in the altered marble, chalk marl/travertine, and top soil (Elie et al., 2007; Khoury, 2015). Limited research was carried out on the the impact of trace elements on the wild plants in central Jordan. The impact dust and heavy metals emitted from petroleum refinery on plant diversity in Tafila / Jordan was investigated
(Oran and Abu Zahra, 2014; Oran and Al- Zo'ubi, 2016). Recent work on central Jordan has indicated that redox sensitive elements are present in the structure of high and low temperature minerals and are adsorbed by the organic matter. of the parent bituminous rocks (Fourcade et al., 2007; Techer et al., 2006; Khoury et al., 2014 and 2015; Khoury et al., 2016). Heavy metals such as U, Cd, $\mathrm{As}, \mathrm{Cr}, \mathrm{Pb}, \mathrm{Ni}, \mathrm{Zn}$ and $\mathrm{V}$ are also enriched in the phosphate rocks of Central Jordan (Abed et al., 2008).

The lack of knowledge of the behavior of some toxic trace elements in soils and plants in Central Jordan in addition to the planned mining activities by Jordan Uranium Mining Company (JUMCO) in the area have encouraged the authors to carry out this work., The transfer of $\mathrm{U}, \mathrm{Cr}$, and $\mathrm{V}$ to the wild plants in terms of sorption, toxicity and speciation will be emphasized.

\section{Materials and methods}

\section{Geology of Central Jordan}

The northern boundaries of the first and second areas of Central Jordan (Daba-Khan Al-Zabib- Siwaqa) are located $25 \mathrm{~km}$ and $60 \mathrm{~km}$ south of Amman with the first area situated between E $36^{\circ} 00^{\prime}$ to $36^{\circ} 15^{\prime}$ and $\mathrm{N} 31^{\circ} 15^{\prime}$ to $31^{\circ} 30^{\prime}$ and the second area between E $35^{\circ} 00^{\prime}$ to $36^{\circ} 15^{\prime}$ and $\mathrm{N} 31^{\circ} 15^{\prime}$ to $31^{\circ} 30^{\prime}$. Fig. 1a shows the location map of the studied area. The studied area was mapped in detail by the Natural Resources Authority (NRA) (Barjous, 1986; Jaser, 1986) and the geology, stratigraphy and sedimentology were described in details by Powell (1989) and Powell and Moh'd (2011).

Fig. 1c is a generalized geological map of the study area (Barjous, 1986; Jaser, 1986; Khoury et al., 2014). Most of the outcropping rocks are of Upper Cretaceous age. The outcropping rocks of Central Jordan are sedimentary in origin and the exposed bed rock ranges in age from Turonian (Upper Cretaceous) to Eocene (Lower Tertiary). Outcrops in central Jordan illustrate the presence of three main rock types: Bituminous marl; varicolored marble (pyrometamorphic rocks); travertine and top soil. The Bituminous Marl Unit overlies the Phosphorite Unit and underlies the varicolored marble and all are of Maestrichtian - Lower Paleocene age (Blake and Ionides, 1939; Quennel, 1956; Burdon, 1959; Barjous, 1986; Jaser, 1986; Khoury et al., 2014). In central Jordan, unusual redox-sensitive elements (RSE) cover large areas and are mainly associated with the varicolored marble, Pleistocene-Recent travertine and top soil. Yellow uranium encrustations and green $\mathrm{Cr}$-rich 
smectites are also associated with the varicolored marble (pyrometamorphic rocks) and the underlying bituminous marl (oil shale) and phosphorites (Khoury, 2006; Khoury and Abu-Jayabb, 1995; Khoury et al., 1984; Khoury et al., 2014). The mineralogy of surficial top soil in central Jordan and RSE source rocks, transport conditions, and deposition processes were explained in detail by Khoury et al. (2014). The geochemistry of uranium and vanadium of the mineral phases was not investigated in detail. The general chronological sequence of the different lithological units is illustrated in Fig. 1d. The Upper Cretaceous to Tertiary rocks in Central Jordan were deposited at the margin of the Tethys shelf-sea in environments ranging from supertidal to deep sub-tidal (Bender, 1986). Transgression took place during Cenomanian times and marine sedimentation continued until the Late Eocene, despite fluctuations in sea level. Gentle folding, block faulting and possible strike- slip faulting were related to continued tectonic movement on the Jordan Rift structure which is located $60 \mathrm{Km}$ to the west of the study area (Bender, 1986; Powell, 1989; Powell and Moh'd, 2011).

\section{Bioclimatic and vegetation regions of Central Jordan}

Central Jordan is classified as arid Mediterranean bioclimate; cool, warm and very warm varieties (Al-Eisawi, 1996). The largest area of Central Jordan is located in arid Mediterranean warm variety bioclimatic zone and located in Irano-Turanian vegetation region, while the north west of Central Jordan is in Mediterranean vegetation region and a very small part of south east of central Jordan located in Saharo-Arabian vegetation regions Fig. 1b. The vegetation is mostly herbs, shrubs and bushes with no trees (Al-Eisawi, 1996).
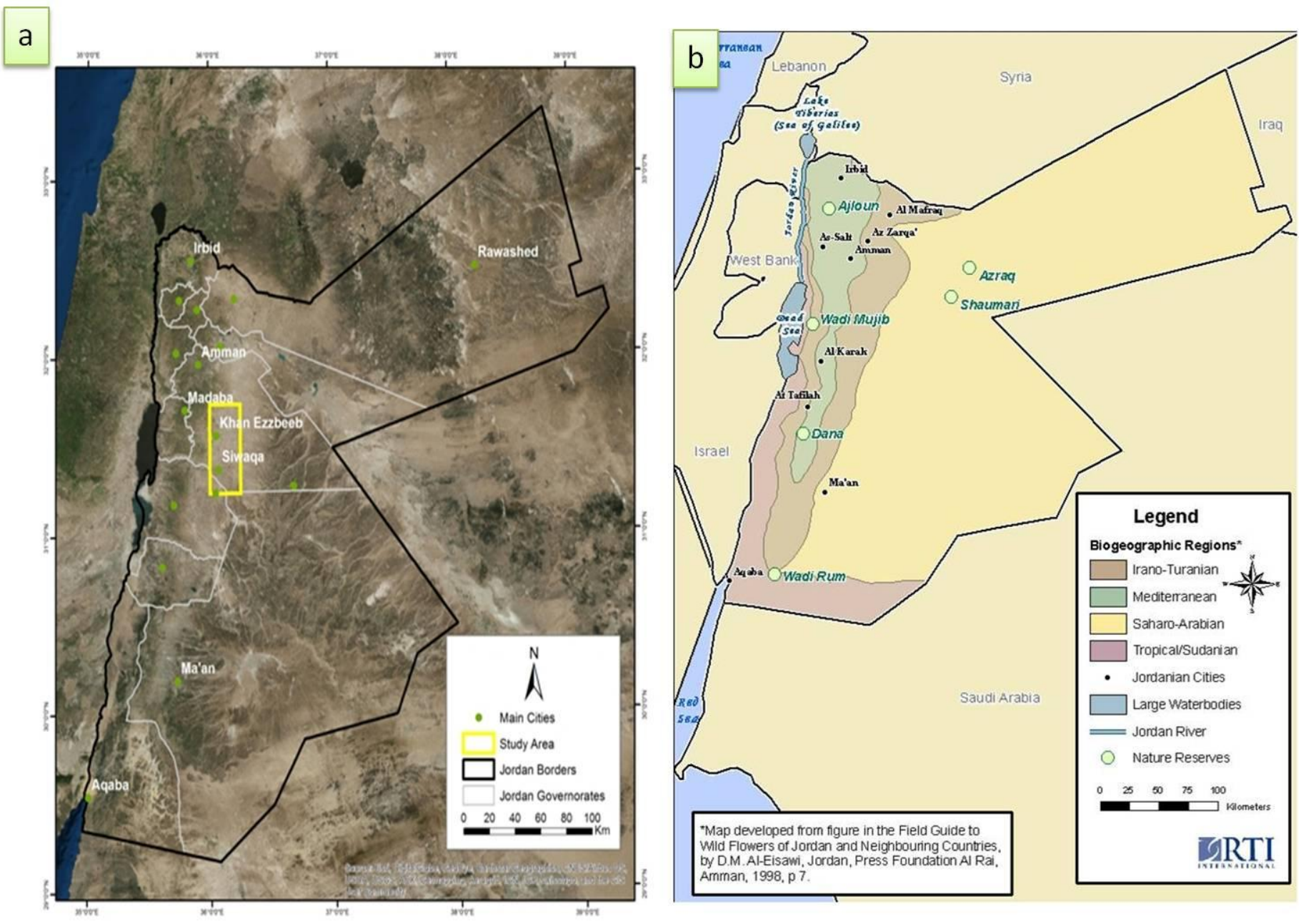

Fig. 1: (a) Location map of Jordan showing the study area/ Central Jordan; (b) Location map of the study area showing the vegetation regions of Central Jordan (after Al-Eisawi, 1996); 

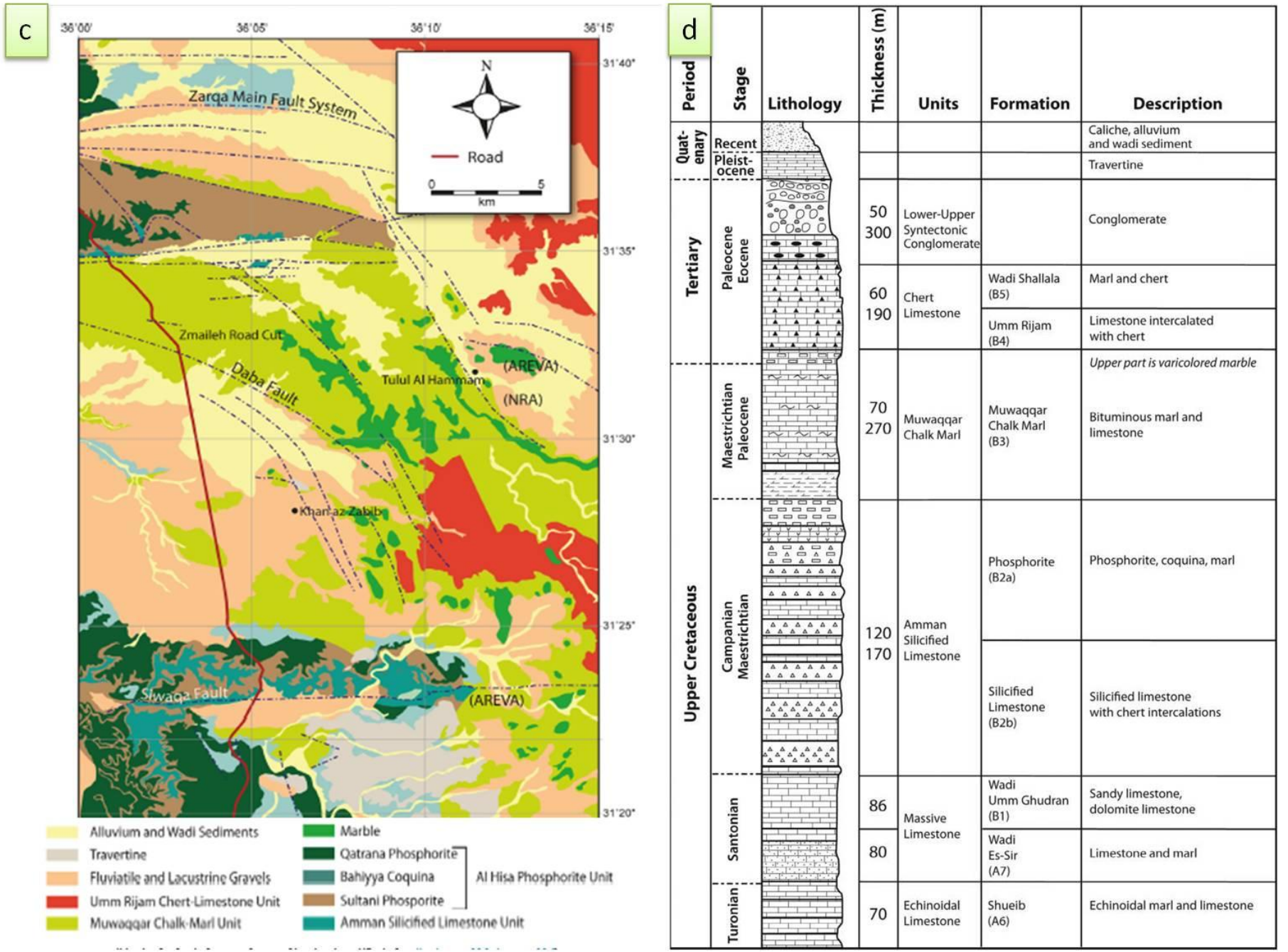

Fig. 1: (c) Geological map of central Jordan (modified after Barjous, 1986; Jaser, 1986; Khoury et al., 2014); (d) Simplified geologic section of central Jordan (modified after Barjous, 1986; Jaser, 1986; Khoury et al., 2014).

\section{Field and laboratory work}

Field trips were conducted extensively to Siwaqa area Central desert of Jordan. Fresh plant specimens and soil samples were collected for every plant species available at the time of sampling and were placed in plastic bags. Global positioning system (GPS) records were made from the sampling sites during the period of the study. Sample locations were chosen randomly referring to the availability of plant species and sampling was based on ease of access, adequate vegetation growth to provide vegetation samples. Plant specimens were identified based on: Flora Palaestina (Parts 1, 2, 3 and 4) (Zohary, 1966; Feinbrun, 1986). Field Guide to Wild Flowers of Jordan and Neighboring Countries (Al-Eisawi, 1998).

Siwaqa area is dry with scare vegetation; wild plants and green grass cover the landscape during Spring time that is used by locals for grazing and as folk medicine (Fig. 2a). A number of 23 soil samples and 23 plant samples were collected. Fig. $2 b$ shows a general view of the landscape in Siwaqa area indicating the scarcity of vegetation cover. The top soil is porous and is mainly composed of calcite and gypsum. Secondary green $\mathrm{Cr}$ rich smectite and yellow uranium minerals are common features filling voids and planes of weakness. Yellow secondary uranium minerals (source of $U$ and $V$ ) together with green $\mathrm{Cr}$ - rich smectites are almost always associated together in the top soil and the underlying travertine and altered marble (Figs. 2c and 2d). Fig. 3 (a-h) are selected photographs of some typical wild plants from Siwaqa area.

Plant samples were carefully brush- washed with tab water and again washed and rinsed with distilled water to remove externally adhered metals and dust from the 
surface of the plants. The plants were oven dried at $100^{\circ} \mathrm{C}$ overnight. The samples were ground in a small coffee grinder. Finally, the samples were ground into fine powder by using Mill mix.

Soil samples were oven dried at $100^{\circ} \mathrm{C}$ overnight, then sieved through 63 microns mesh screen into fine powder. The samples were characterized using chemical methods. All the analytical work was carried out in the laboratories of the Department of Geology, University of Jordan and the Jordan Atomic Energy Commission (JAEC).

Inductively coupled plasma mass spectrometry (ICPMS) analyses were carried out in the Chemical Analysis Section, chemical and physical analysis laboratories, Nuclear Fuel Cycle Commission (NCC- CPAL), Jordan
Atomic Energy Commission (JAEC). The ICP- MS (ELAN® DRC-e, PerkinElmer SCIEX) was used to measure the amount of toxic trace elements in plants and soil particles. All samples were sent via Jordanian Uranium Mining Company (JUMCO) to ALS Arabia Co. Ltd. Jeddah, Saudi Arabia to be analyzed.

The TF was used as an index for the accumulation of trace elements by plants or the transfer of elements from soil to plants in $\mathrm{mg} / \mathrm{kg}$ (Whicker et al., 1999; Yanagisawa et al., 1992). The transfer factor TF is defined as a factor used to describe the amount of element which is expected to be transferred to plant from soil. It is also defined as the ratio of specific activities in plant parts and soil (in $\mathrm{Bq} / \mathrm{kg}$ dry weight plant part divided by $\mathrm{Bq} / \mathrm{kg}$ dry weight soil).
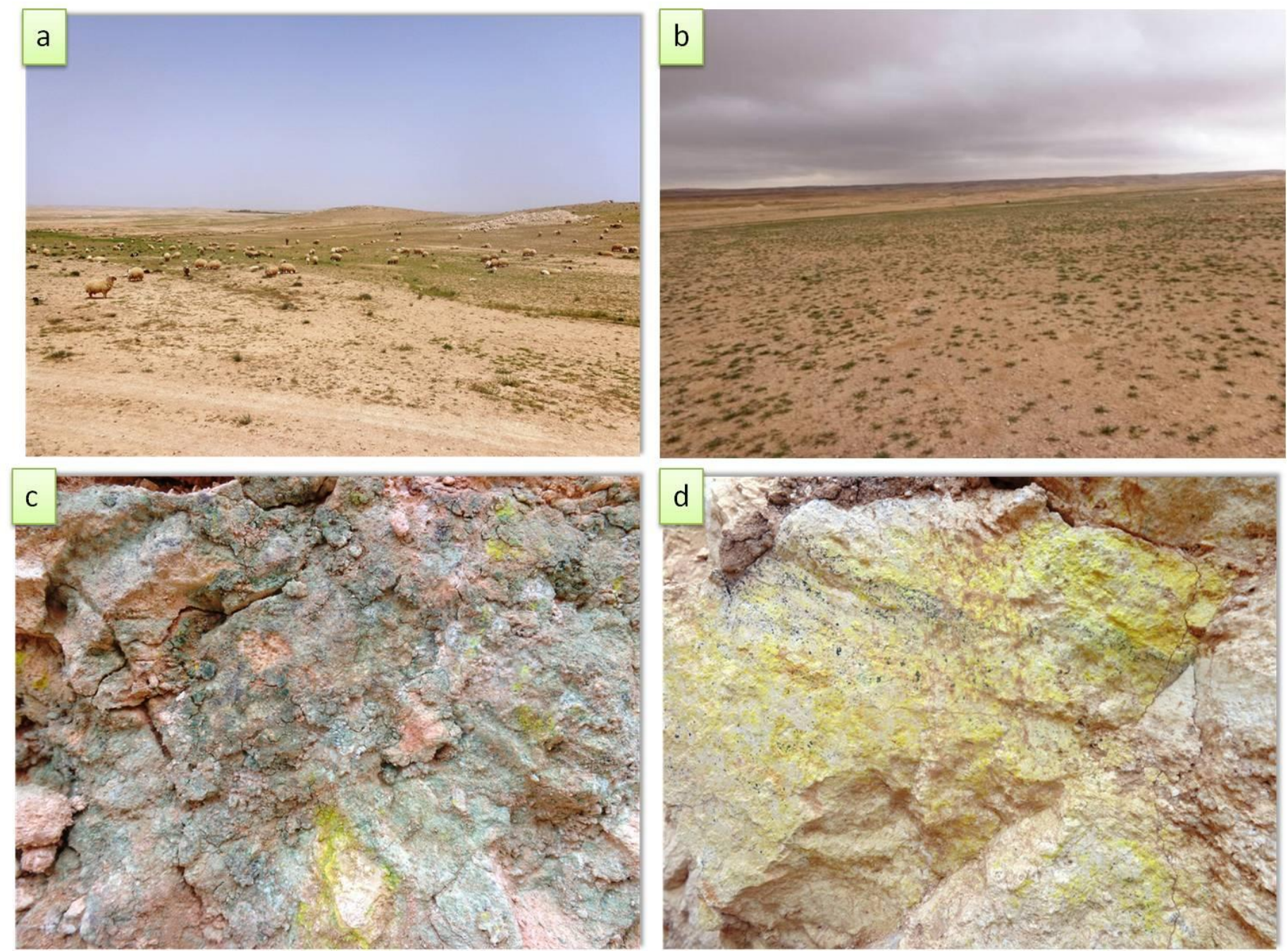

Fig. 2: (a) Landscape of the study area showing grazing by herbavious animals; (b) A Photograph showing a general view of the landscape indicating the scarcity of vegetation cover; (c) A photograph illustrates the presence of secondary encrustations of uranium and Cr-rich smectites in the altered marble/top soil; (d) A phtograph of yellow secondary uranium minerals filling porous rocks.

A. F. Bzour et al. (2016) / Assessment of Bioavailability of Chromium (Cr), Vanadium (V) and Uranium (U) in Wild Plants in Siwaqa Area, Central Jordan 

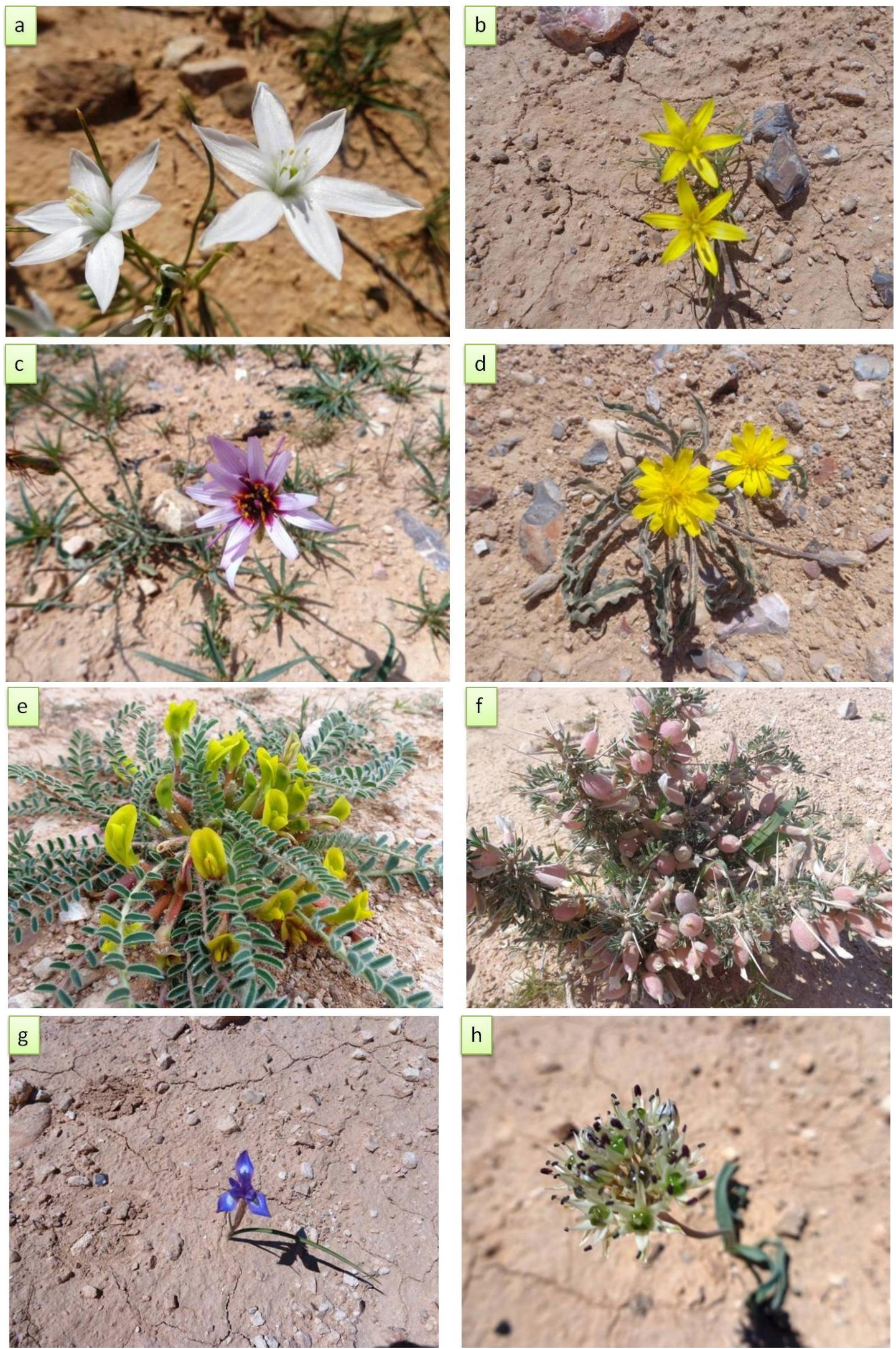

Fig. 3: Photographs of wild plants (a) Ornithogalum trichophyllum; (b) Gagea reticulate; (c.) Scorzonera papposa; (d) Scoronozera schweinfurthii; (e) Astragalus sparsus; (f) Astragalus spinosus; (g) Gynandriris sisyrinchium; (h) Allium rothii.

A. F. Bzour et al. (2016) / Assessment of Bioavailability of Chromium (Cr), Vanadium (V) and Uranium (U) in Wild Plants in Siwaqa Area, Central Jordan 


\section{Results and discussion}

In homogeneous unusual surface RSE (U, V and $\mathrm{Cr}$ ) hosted by the top soil covers large areas in central Jordan. The secondary uranium mineralization is restricted to the permeable fractured and porous zones. The combustion of the bituminous marl led to the formation of the in central Jordan (Khoury et al., 2014). The action of circulating highly alkaline water that accelerated the leaching process of the redox sensitive trace elements such as $\mathrm{U}, \mathrm{Cr}$ and V. Such an alkaline oxidizing environment ( $\mathrm{pH} 12.7)$ is currently active in Maqarin area, north Jordan (Khoury, 2012 and 2014).
The uranyl-vanadate minerals strelkinite and/or tyuyamunite $\left(\mathrm{Na}_{2}\left(\mathrm{UO}_{2}\right)_{2}\left(\mathrm{~V}_{2} \mathrm{O}_{8}\right) \cdot 6 \mathrm{H}_{2} \mathrm{O}\right.$ and $\mathrm{Ca}\left(\mathrm{UO}_{2}\right)_{2}$ $\left.\left(\mathrm{VO}_{4}\right) 2 \cdot 5-8 \mathrm{H}_{2} \mathrm{O}\right)$ and $\mathrm{Cr}$-rich smectite were precipitated from highly alkaline solutions during the dry periods after the precipitation of the thick travertine deposits (Khoury et al., 2014).

\section{Mass Spectrometry analysis (ICP- MS) results}

The mass spectrometry analysis (ICP- MS) results are given in Table 1 . The table includes the concentration results of $\mathrm{U}, \mathrm{V}$, and $\mathrm{Cr}$ in the soil and plant samples in addition to the calculated transfer factors.

Table 1. Trace elements concentrations $(\mathrm{mg} / \mathrm{kg})$ in soil, plant and their TFs of Siwaqa area.

\begin{tabular}{|c|c|c|c|c|c|c|c|c|c|c|}
\hline \multirow{2}{*}{$\begin{array}{l}\text { Location } 1 \\
\text { Sample ID }\end{array}$} & \multicolumn{3}{|l|}{ Soils } & \multirow{2}{*}{ Plant name } & \multicolumn{3}{|l|}{ Plants } & \multicolumn{3}{|l|}{ TF } \\
\hline & $\mathrm{Cr}$ & $\mathbf{U}$ & $\mathbf{V}$ & & $\mathrm{Cr}$ & $\mathbf{U}$ & $\mathbf{V}$ & $\mathrm{Cr}$ & $\mathbf{U}$ & $\mathbf{V}$ \\
\hline 2 & 48.4 & 4.93 & 57.5 & Arthocnemum mucronatum & 3.51 & 0.182 & 2.9 & 0.07 & 0.04 & 0.05 \\
\hline 4 & 49.2 & 3.55 & 56.5 & Onopordum transjordanicum & 22.9 & 0.882 & 14.5 & 0.5 & 0.25 & 0.25 \\
\hline 5 & 42.2 & 6.9 & 62.8 & Bellevalia sp. & 26.6 & 1.365 & 16.6 & 0.6 & 0.2 & 0.26 \\
\hline 6 & 51.1 & 7.09 & 65.7 & Astragalus sp. & 10.4 & 0.62 & 7.2 & 0.2 & 0.1 & 0.11 \\
\hline 9 & 66.6 & 1.83 & 52 & Scorzonera schweinfurthii & 3.14 & 0.141 & 2.4 & 0.05 & 0.08 & 0.046 \\
\hline 10 & 55.1 & 3.02 & 84.4 & Senecio flavus & 9.22 & 0.596 & 12.1 & 0.2 & 0.2 & 0.14 \\
\hline 11 & 52.2 & 3.76 & 94.1 & Peganum harmala & 11.95 & 0.357 & 7.1 & 0.2 & 0.1 & 0.075 \\
\hline 12 & 65.5 & 3.87 & 63.3 & Onopordum transjordanicum & 16.7 & 0.539 & 7.5 & 0.25 & 0.14 & 0.12 \\
\hline 14 & 81.5 & 24.8 & 100.5 & Hordeum glaucus & 11.75 & 3.78 & 6 & 0.1 & 0.15 & 0.06 \\
\hline 26 & 75.3 & 30.2 & 115.5 & Malva sylvestris & 14.5 & 3.11 & 12.6 & 0.2 & 0.1 & 0.12 \\
\hline 32 & 56.1 & 8.68 & 58.5 & Matthiola sp. & 5.44 & 0.844 & 2.5 & 0.1 & 0.1 & 0.04 \\
\hline 33 & 56.7 & 4.4 & 59.2 & Allium rothii & 13.55 & 0.912 & 11 & 0.2 & 0.2 & 0.2 \\
\hline 34 & 60.2 & 6.31 & 71.9 & Gymnarrhena micrantha & 8.92 & 0.904 & 5.1 & 0.15 & 0.14 & 0.07 \\
\hline 35 & 59.1 & 8.91 & 73.5 & Maresia pygmaea & 8.09 & 0.682 & 4.6 & 0.1 & 0.08 & 0.06 \\
\hline 36 & 68.8 & 6.64 & 76.6 & Gynandriris sisyrinchium & 12.1 & 0.589 & 6.4 & 0.2 & 0.1 & 0.08 \\
\hline Mean & 60.98 & 12.64 & 79.31 & & 11.65 & 1.497 & 8.265 & 0.2061 & 0.1232 & 0.107 \\
\hline STADE & 14.19 & 14.59 & 26.63 & & 6.153 & 1.844 & 4.759 & 0.1375 & 0.0574 & 0.06507 \\
\hline $\begin{array}{l}\text { Std. Error of } \\
\text { Mean }\end{array}$ & 2.958 & 3.042 & 5.553 & & 1.283 & 0.3844 & 0.9923 & 0.02867 & 0.01197 & 0.01357 \\
\hline Minimum & 42.2 & 1.83 & 52 & & 1.19 & 0.05 & 0.7 & 0.02 & 0.024 & 0.01 \\
\hline Median & 59.1 & 6.62 & 67.1 & & 11.95 & 0.682 & 7.2 & 0.2 & 0.1 & 0.08 \\
\hline Maximum & 108 & 56.8 & 142 & & 26.6 & 7.38 & 17.7 & 0.6 & 0.25 & 0.26 \\
\hline
\end{tabular}

The abundance of $\mathrm{Cr}$ in the Earth's upper crust averages $100 \mathrm{mg} / \mathrm{kg}$ (Pendias and Pendias, 2000). Chromium enters the air, water, and soil mostly in the chromium (III) and chromium (VI) forms. In air, chromium compounds are present mostly as fine dust particles which eventually settle over land and water. The main reason of the toxicity of $\mathrm{Cr}$ (VI) is that one of the reduction products of $\mathrm{Cr}(\mathrm{VI})$ is $\mathrm{Cr}(\mathrm{V})$. Chrome
(V) is a known as carcinogenic and will lodge in any tissue to form cancerous growths. WHO (2007) and Pendias and Pendias (2000), recommended that 75 $\mathrm{mg} / \mathrm{kg} \mathrm{Cr}$ in soil is critical concentration to be toxic. WHO (2007) recommended that $1.3 \mathrm{mg} / \mathrm{kg}$ is the toxic limit to plant species. The concentrations of $\mathrm{Cr}$ in soils of Siwaqa area range between 42.2 to $108 \mathrm{mg} / \mathrm{kg}$ with a mean value of $60.98 \mathrm{mg} / \mathrm{kg}$. Three soil samples 
have exceeded the permissible limit of $\mathrm{Cr}$ in the soil as recommended by WHO (2007) and Pendias and Pendias (2000). The highest value of $\mathrm{Cr}$ content in plant species of Siwaqa area is $26.6 \mathrm{mg} / \mathrm{kg}$ and recorded in Bellevalia sp. The lowest value of $\mathrm{Cr}$ content is $1.19 \mathrm{mg} / \mathrm{kg}$ and is recorded in Allium rothii. The mean value is $11.65 \mathrm{mg} / \mathrm{kg}$. Only Allium rothii has $\mathrm{Cr}$ concentration below the toxic limit as recommended by WHO (2007). Fig. 4 shows the $\mathrm{Cr}$ concentrations in plant species of Siwaqa area. The TF for $\mathrm{Cr}$ from soil to plant of Siwaqa area ranges from 0.02 to 0.6 with a mean value of 0.21 . The highest TF value is found in Bellevalia sp. and the lowest TF is found in Allium rothii.

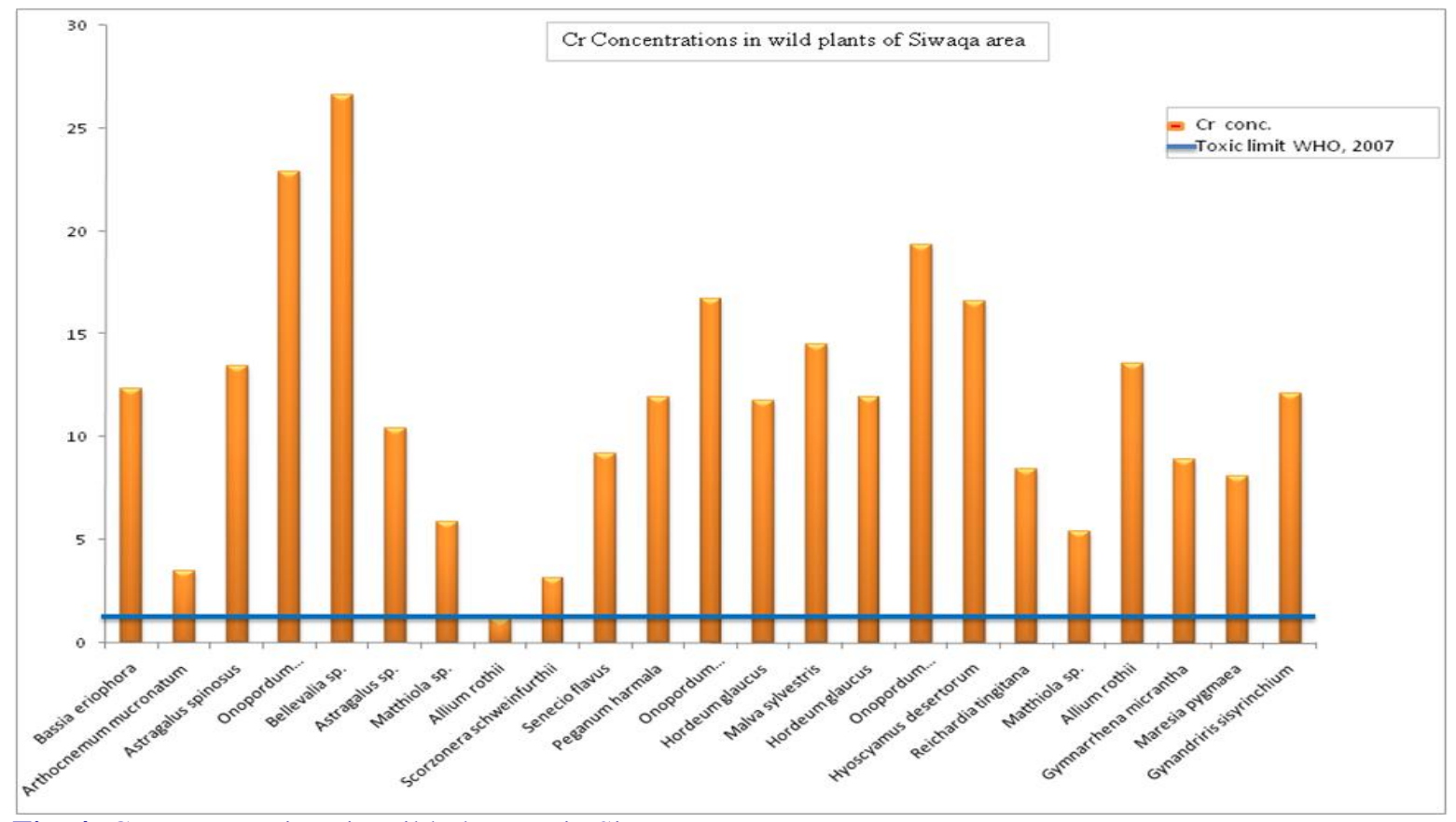

Fig. 4: Cr concentrations in wild plant sp. in Siwaqa area.

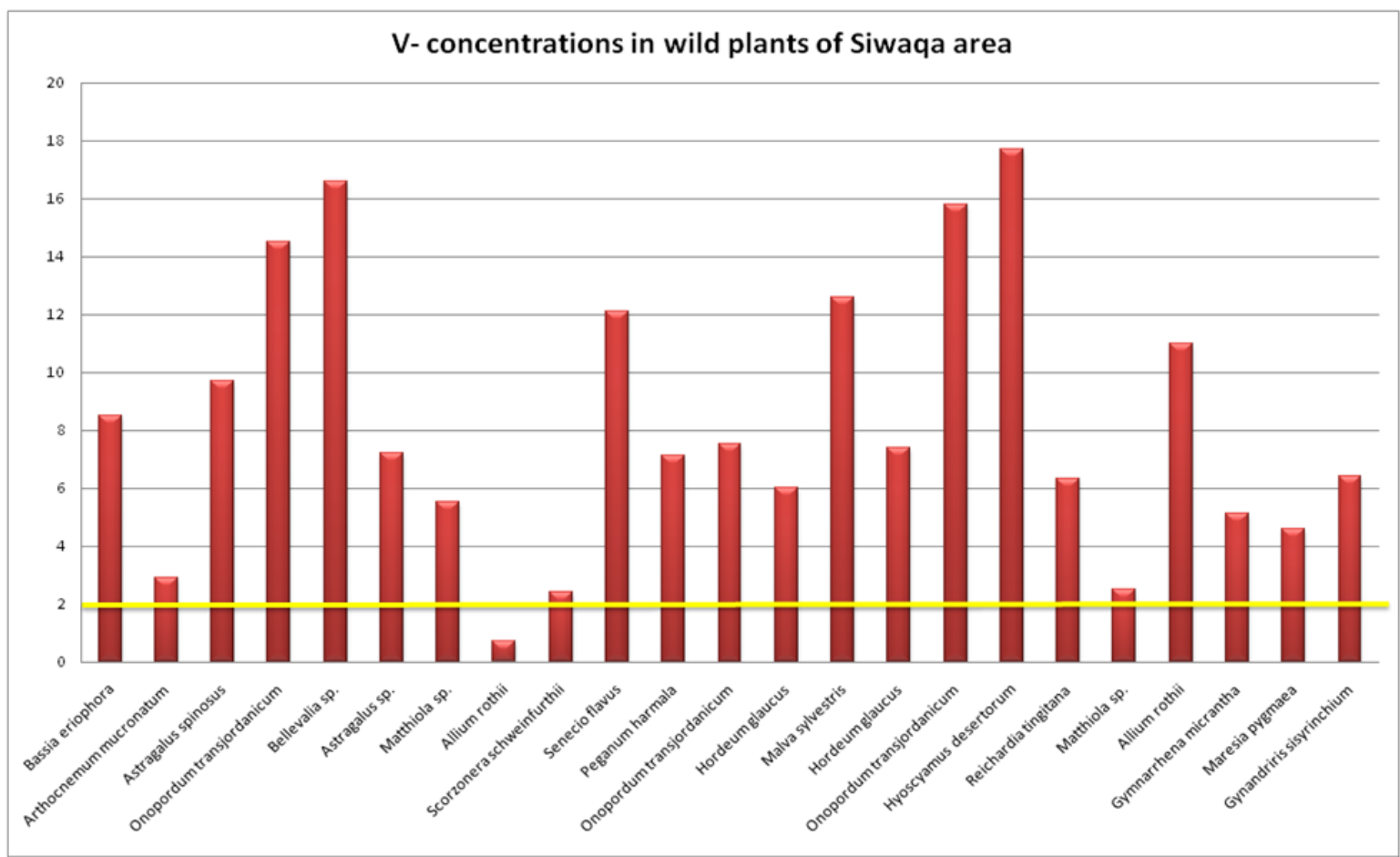

Fig. 5: V concentrations in wild plant species of Siwaqa area. 
Levels of V in soils are closely related to the parent rock types. Its worldwide soil average is estimated at 129 $\mathrm{mg} / \mathrm{kg}$, within the range of $69-320 \mathrm{mg} / \mathrm{kg}$ (Pendias and Pendias, 2000). WHO (2007) recommended that $2 \mathrm{mg} / \mathrm{kg}$ $\mathrm{V}$ concentration is toxic to plants. The concentrations of $\mathrm{V}$ in soils of Siwaqa area range between 52 to $142 \mathrm{mg} / \mathrm{kg}$ with a mean value of $79.31 \mathrm{mg} / \mathrm{kg}$. The highest value of $\mathrm{V}$ concentration in plant species of Siwaqa area is 17.7 $\mathrm{mg} / \mathrm{kg}$ and is recorded in Hyoscyamus desertorum and the lowest $\mathrm{V}$ concentration value is $0.7 \mathrm{mg} / \mathrm{kg}$ and is recorded in Allium rothii. The mean value is $8.27 \mathrm{mg} / \mathrm{kg}$. Only one species of Siwaqa area has a concentration value below the toxic limit as recommended by WHO (2007). Fig. 5 shows the V concentrations in plant species of Siwaqa area. The TF for V from soil to plant of Siwaqa area ranges from 0.01 to 0.26 with a mean value of 0.11 . The highest TF is found in Astragalus sp. The lowest TF is found in Allium rothii.

Exposure to uranium can result in both chemical and radiological toxicity. The main chemical effect associated with exposure to uranium and its compounds is kidney toxicity. This toxicity can be caused by breathing air containing uranium dusts or by eating substances containing uranium, which then enters the bloodstream. Once in the bloodstream, the uranium compounds are filtered by the kidneys, where they can cause damage to the kidney cells. Very high uranium intakes can cause acute kidney failure and death (ATSDR, 2005; Sheppard et al., 1985). The toxic limit for $U$ concentrations in soils and plants are 1 and 0.3 respectively recommended by WHO (2007). The concentrations of $U$ in soils of Siwaqa area range between 1.83 to $56.8 \mathrm{mg} / \mathrm{kg}$ with a mean value of 12.64 $\mathrm{mg} / \mathrm{kg}$. All soil samples have exceeded the toxic limit of $\mathrm{U}$ concentration in soils as recommended by WHO (2007). The highest value of $U$ content in plant species of Siwaqa area is $7.38 \mathrm{mg} / \mathrm{kg}$ and is recorded in Onopordum transjordanicum. The lowest value of $\mathrm{U}$ content is $0.05 \mathrm{mg} / \mathrm{kg}$ and is recorded in Allium rothii. The mean value is $1.497 \mathrm{mg} / \mathrm{kg}$. Fig. 6 shows that the most collected plant species of the Siwaqa area have U concentrations above the toxic limit as recommended by WHO (2007). The TF for U from soil to plant of Siwaqa area ranges from 0.024 to 0.25 with a mean value of 0.123. The highest $\mathrm{TF}$ is found in Onopordum transjordanicum and the lowest $\mathrm{TF}$ value is found in Allium rothii.

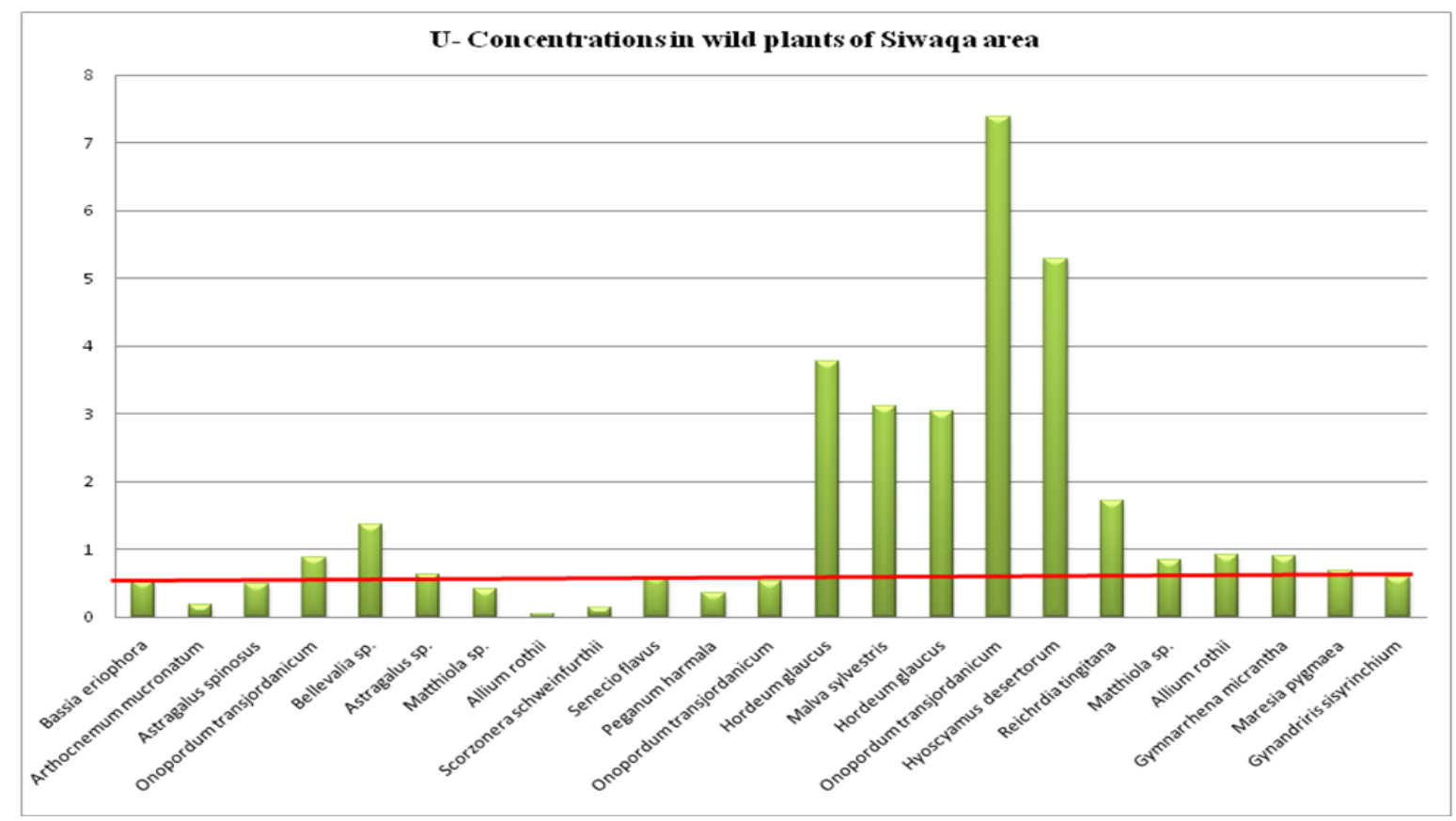

Fig. 6: U concentrations in wild plant species of Siwaqa area.

\section{Conclusion}

The present study has been conducted to assess wild plant species in Siwaqa area/ Central Jordan for the absorption of different hazardous trace elements. The environmental geochemical survey has revealed variations of trace elements concentrations in soils and plant species. The sources of trace elements are related to the leaching processes from the parent rocks of the area. The concentration of these elements was depending on 
climatic geologic events in Central Jordan. Differences between trace elements TFs values for various plant species are related to the different characteristics and behavior of the wild plants. In general, the comparative uptake of trace elements is affected by numerous physical, chemical and biological conditions of the soil. The uptake of elements by plants depends on the plant species and the concentration of elements in the soil. The values are above the permissible limits according to world health organization (WHO). The information on the concentration level and transfer of $\mathrm{Cr}, \mathrm{V}$ and $\mathrm{U}$ from soil to plant will provide important information during the environment risk assessment that is expected to be carried out by JUMCO in the near future. Further studies and investigations are needed to assess and evaluate the ecotoxicity of heavy metals on plant species by the different RSE in the different soils of Central Jordan.

\section{Conflict of interest statement}

Authors declare that they have no conflict of interest.

\section{Acknowledgement}

The financial help of the Deanship of Academic Research, University of Jordan and the Jordanian Uranium Mining Company (JUMCO) is highly appreciated. Special thanks are given to Dr. Samer Kahook and Dr. Hussein Allaboun from JUMCO for their support during the progress of this work.

\section{References}

Abed, A., Al-Eisawi, D., 1994. The geobotanical exploration for Copper and Manganese in north- eastern Wadi Araba, Jordan. Dirasat. 21(3), 189-201.

Abed, A., Sadaqah, R., Al Kuisi, M., 2008. Uranium and potentially toxic metals during the mining, beneficiation, and processing of phosphorite and their effects on ground water in Jordan. Mine Water Environ. 27(3), 171-182.

Al-Eisawi, D. M., 1996. Vegetation of Jordan. Book published by UNESCO (ROSTAS), Cairo Office, Cairo. 284p.

Al-Eisawi, D. M., 1998. The Field Guide to Wild Flowers of Jordan and Neighboring Countries. Press Foundation,AlRai. 296p.

Atrouz, O., Oran, S., Abadi, S., 2004. Chemical analysis and pollen grains identification of different Jordanian honey samples. Int. J. Food Sci. Tech. 39, 413-417.

Agency for Toxic Substances and Disease Registry (ATSDR), 2005. Toxicological Profile for Arsenic (Draft for public comment). U.S. Department of Public Health and Human Services, Public Health Service, Atlanta, GA.

Barjous, M., 1986. The Geology of Siwaqa. Bull. 4, NRA, Amman, Jordan.
Bender, F., 1968. Geologie von Jordanian. Beitrage zur Regionalen Geologie der Erde, Band 7. Borntraeger, Berlin.

Blake, G., Ionides, M., 1939. Report on the Water Resources of Transjodan and their Development. Crown Agents for Colonies, London.

Buck, E. C., Brown, N. R., Dietz, N. L., 1996. Contaminant uranium phases and leaching at the Fernald site in Ohio. Environ. Sci. Technol. 30, 81-88.

Burdon, D., 1959. Handbook of the Geology of Jordan. Benham and Company Ltd., Colchester.

Chen, S. B., Zhu, Y. G., Hu, Q. H., 2005. Soil to plant transfer of ${ }^{238} \mathrm{U},{ }^{226} \mathrm{Ra}$ and ${ }^{232} \mathrm{Th}$ on a uranium mining-impacted soil from southeastern China. J. Environ. Radioact. 82, 223-236.

Djingova, R., Kuleff, I., 2000. Instrumental techniques for trace analysis. In: Trace Elements: Their Distribution and Effects in the Environment (Ed.: Vernet, J. P.). Elsevier Science Ltd., United Kingdom. 146p.

Elie, M., Techer, I., Trotignon, L., Khoury, H. N, Salameh, E., Vandamme, D., Boulvais, P. Fourcade, S., 2007. Cementation of kerogen-rich marls by alkaline fluids released during weathering of thermally metamorphosed marly sediments. Part II: Organic matter evolution, magnetic susceptibility and metals ( $\mathrm{Ti}, \mathrm{Cr}, \mathrm{Fe}$ ) at the Khushaym Matruck natural analogue (central Jordan). Appl. Geochem. 22, 1311-1328.

Feinbrun, N., 1986. Flora Palaestina. Vol. III, IV. The Israel Academy of Sciences and Humanities, Jerusalem.

Fourcade, S., Trotignon, L., Boulvais, P., Techer, I., Elie, M., Vandamme, D., Salameh, E., Khoury, H. N, 2007. Cementation of kerogen-rich marls by alkaline fluids released during weathering of thermally metamorphosed marly sediments. Part I: Isotopic $(\mathrm{C}, \mathrm{O})$ study of the Khushaym Matruk natural analogue (central Jordan). Appl. Geochem. 22, 1293-1310.

Hamilton, El., 1995. State of the art of trace element determinations in plant matrices: Determination of the chemical elements in plant matrices, an overview. Sci. Total Environ. 176, 3-14.

Jaser, D., 1986. The geology of Khan Ez Zabib, Bull. NRA. Amman, Jordan, 3p.

Khoury, H. N., 2014. Geochemistry of surficial uranium deposits from central Jordan. Jordan J. Earth Environ. Sci. 6(3), 11-22.

Khoury, H. N., 2006. Industrial Rocks and Minerals in Jordan. $2^{\text {nd }}$ Edn. Publications of the University of Jordan, Jordan.

Khoury, H. N., Nassir, S., 1982. A discussion on the origin of Daba - Siwaqa marble. Dirasat. 9, 55-56.

Khoury, H. N., 2012. Long-term analogue of carbonation in Travertine from Uleimat Quarries, Central Jordan. Environ. Earth Sci. 65, 1906-1916.

Khoury, H. N., 2015. Uranium minerals of Central Jordan. Appl. Earth Sci. (Trans. Inst. Min. Metall. B). 124(2), 104-128.

Khoury, H. N., Abu-Jayyab, A., 1995. A short note on the mineral volkonskoite. Dirasat. 1, 189-198. 
Khoury, H.N., Kokh, S., Sokol, E., Likhacheva, A., Seryotkin, Y., Belogub, E., 2016. Ba- and Sr-mineralization of fossil fish bones from metamorphosed Belqa Group sediments, central Jordan. Arabian J. Geosci. 9, 461.

Khoury, H. N., Mackenzie, R., Russell, J., Tait, J., 1984. An iron-free volkonskoite. Clay Minerals. 19, 43-57.

Khoury, H. N., Salameh, E., Clark, I., 2014. Mineralogy and origin of surficial uranium deposits hosted in travertine and calcrete from central Jordan. Appl. Geochem. 43, 49-65.

Khoury, H. N., Sokol, E., Clark, I., 2015. Calcium uranium oxides from central Jordan: associations, chemistry, and alteration products. Canad. Mineralogist. 53, 61-82.

Levy, D. B., Barbarick, K. A., Siemer, E. G., Sommers, L. E., 1992. Distribution and partitioning of trace metals in contaminated soils near Leadville, Colorado. J. Environ. Qual. 21(2), 185-195.

Nassir, S., Khoury, H. N., 1982. Geology, mineralogy and petrology of Daba marble, Jordan. Dirasat. 9(1), 107-140.

Oran, S. A., Al-Zo'ubi, E., 2016. The impact of the emitted dust from Zarka (Jordan) petroleum refinery on plant biodiversity. Int. J. Curr. Res. Biosci. Plant Biol. 3(6), $1-13$.

Oran, S. A., Abu Zahra, H., 2014. Impact of the cement dust emitted from the south cement factory in Tafila/ Jordan on plant diversity of the surrounding area. Int. J. Biodiv. Conserv. 6(5), 400-414.

Pendias, A. K., Pendias, H., 2000. Trace Elements in Soils and Plants. 3. CRC Press, FL, United States. pp.10-11.

Pierzynski, G. M., Sims, J. T., Vance, G. F., 2000. Soils and Environmental Quality. $2^{\text {nd }}$ Edn. CRC Press, London, UK.

Powell, J. H., 1989. Stratigraphy and Sedimentology of the Phanerozoic Rocks in Central and Southern Jordan. Bull. 11, Geology Directorate, Natural Resources Authority (Ministry of Energy and Mineral resources) Amman, Part B: Kurnub, Ajlun and Belqa Group, 161P.

Powell, J. H., Moh'd, B. K., 2011. Evolution of Cretaceous to Eocene alluvial and carbonate platform sequences in central and south Jordan. GeoArabia. 16(4), 29-82.

Quennel, A., 1956. The structural and geomorphic evaluation of the Dead Sea Rift. Quart. J. Geol. Sci. Lond. 64, 1-24.

Sheppard, M. I., Sheppard, S. C., 1985. The plant concentration ratio concept as applied to natural U. Health Phys. 48, 494-500.

Shiowatana, J., McLaren, R., Chanmekha, N., Samphao, A., 2001. Fractionation of arsenic in soil by a continuous-flow sequential extraction method. J. Environ. Qual. 30(6), 1940-1949.

Techer, I., Khoury, H. N., Salameh, E., Rassineux, F., Claude, C., Clauer, N., Pagel, M., Lancelot, J., Hamelin, B., Jacquot, E., 2006. Propagation of high-alkaline fluids in an argillaceous formation: Case study of the Khushaym Matruk natural analogue (Central Jordan). J. Geochem. Explorat. 90, 53-67.

Tomé, V., Rodrigues, P., Lozano, J., 2002. Distribution and mobilization of $\mathrm{U}$, Th and ${ }^{226} \mathrm{Ra}$ in the plant- soil compartments of a mineralized uranium area in Southwest Spain. J. Environ. Radioact. 59, 223-243.

Whicker, F.W., Hinton, T.G., Orlandini, K.A., Clark, S.B., 1999. Uptake of natural and anthropogenic actinides in vegetable crops grown on a contaminated lake bed. J. Environ. Radioact. 45, 1-12.

Wilson, B., Pyatt, B., 2007. Heavy metal dispersion, persistence and bioaccumulation around an ancient copper mine situated Anglesey, UK. Ecotoxicol. Environ. Saf. 66, 224-231.

World Health Organization (WHO), 2007. Joint FAO/WHO Expert standards program codex Alimentation Commission. Geneva, Switzerland. Available, onlinehttp://www.who.int [Accessed 10/09/2012].

Yanagisawa, K., Muramatsu, Y., Kamada, H., 1992. Tracer experiments on the transfer of technetium from soil to rice and wheat plants. Radioisotopes. 41, 397- 402.

Zohary, M., 1966. Flora Palaestina. Vol. I, II, III. The Israel Academy of Sciences and Humanities, Jerusalem.

\section{How to cite this article:}

Bzour, A. F., Khoury, H. N., Oran, S. A., 2016. Assessment of bioavailability of chromium (Cr), vanadium (V) and uranium (U) in wild plants in Siwaqa Area, Central Jordan. Int. J. Curr. Res. Biosci. Plant Biol. 3(12), 8494. doi: http://dx.doi.org/10.20546/ijcrbp.2016.312.010 